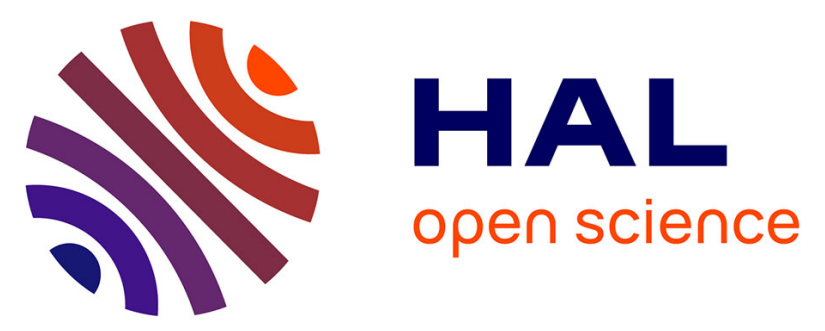

\title{
Long-term outcomes of refractory neurosarcoidosis treated with infliximab
}

\author{
Fleur Cohen Aubart, Diane Bouvry, Damien Galanaud, Caroline Dehais, \\ Guillaume Mathey, Dimitri Psimaras, Julien Haroche, Corinne Pottier, Miguel \\ Hie, Alexis Mathian, et al.
}

\section{To cite this version:}

Fleur Cohen Aubart, Diane Bouvry, Damien Galanaud, Caroline Dehais, Guillaume Mathey, et al.. Long-term outcomes of refractory neurosarcoidosis treated with infliximab. Journal of Neurology, 2017, 264 (5), pp.891-897. 10.1007/s00415-017-8444-9 . hal-01520373

\section{HAL Id: hal-01520373 https://hal.sorbonne-universite.fr/hal-01520373}

Submitted on 10 May 2017

HAL is a multi-disciplinary open access archive for the deposit and dissemination of scientific research documents, whether they are published or not. The documents may come from teaching and research institutions in France or abroad, or from public or private research centers.
L'archive ouverte pluridisciplinaire HAL, est destinée au dépôt et à la diffusion de documents scientifiques de niveau recherche, publiés ou non, émanant des établissements d'enseignement et de recherche français ou étrangers, des laboratoires publics ou privés. 


\section{Long-term outcomes of refractory neurosarcoidosis treated with infliximab}

Running title: Infliximab for neurosarcoidosis

Fleur Cohen Aubart ${ }^{1,2}, \mathrm{MD}, \mathrm{PhD}$, Diane Bouvry ${ }^{3}, \mathrm{MD}$, Damien Galanaud ${ }^{2,4}, \mathrm{MD}, \mathrm{PhD}$, Caroline Dehais $^{5}, M D, P h D$, Guillaume Mathey ${ }^{6}, M D$, Dimitri Psimaras ${ }^{5}, M D$, Julien Haroche ${ }^{1,2}, M D$, $\mathrm{PhD}$, Corinne Pottier ${ }^{7}, \mathrm{MD}$, Miguel Hie ${ }^{1}, \mathrm{MD}$, Alexis Mathian ${ }^{1}, \mathrm{MD}, \mathrm{PhD}$, Hervé Devilliers ${ }^{8}$, $\mathrm{MD}, \mathrm{PhD}$, Hilario Nunes ${ }^{3}, \mathrm{MD}, \mathrm{PhD}$, Dominique Valeyre ${ }^{3}, \mathrm{MD}, \mathrm{PhD}$ and Zahir Amoura ${ }^{1,2}, \mathrm{MD}$, MSc

1. AP-HP, Service de Médecine Interne 2, Institut e3m, Centre National de Référence Maladies Auto-immunes Systémiques Rares, Groupe Hospitalier Pitié-Salpétrière, Paris75013, France

2. Université Paris VI Pierre et Marie Curie, Sorbonnes Universités, Paris-75013, France

3. AP-HP, Service de Pneumologie, Hôpital Avicenne, Bobigny-93000, France

4. AP-HP, Service de Neuroradiologie Diagnostique et Fonctionnelle, Groupe Hospitalier Pitié-Salpêtrière, Paris-75013, France

5. AP-HP, Service de Neurologie, Groupe Hospitalier Pitié-Salpêtrière, Paris-75013, France

6. Service de Neurologie, Centre hospitalier Régional de Metz-Thionville, Ars-Laquenexy57530, France

7. Service de Neurologie, Centre Hospitalier René Dubos, Pontoise-95300, France

8. Service de Médecine Interne, University Hospital, Dijon-21000, France

Correspondence to Dr. Fleur Cohen Aubart, Service de Médecine Interne 2, Institut e3m, Hôpital de la Pitié-Salpêtrière, 47-83 Boulevard de l'hôpital, 75651 PARIS CEDEX 13, France

Email fleur.cohen@aphp.fr

Phone +33142178242

Fax +33142165804

Word count in full text: $2029(<1500)$

Word count in abstract: 250 (< or $=250)$

Character count in title including spaces: $73(<96)$

Number of tables: 2 
Number of figures: 1 (Total < or $=3$ )

Number of references: 23

Key words: neurosarcoidosis, infliximab, relapses, side effects

Figure legend. Efficacy of TNF-alpha antagonists. Modified Rankin scores (A) and corticosteroid dosages (B) at baseline and at the end of follow-up. Medians with IQR are plotted. mRS modified Rankin scale. IQR: interquartile range.

\section{Conflicts of interest}

The authors declare no conflicts of interest and no disclosures relevant to the manuscript. This work did not receive any funding.

\section{Authors contribution}

All the authors (F. Cohen Aubart, D. Bouvry, D. Galanaud, C. Dehais, G. Mathey, D. Psimaras, J. Haroche, C. Pottier, M. Hie, A. Mathian, H. Devilliers, H. Nunes, D. Valeyre, and Z. Amoura) contributed to drafting/revising the manuscript for content, study design and analysis and interpretation of the data.

F. Cohen Aubart, D. Bouvry, D. Galanaud and G. Mathey contributed to acquisition of data.

F. Cohen Aubart conducted the statistical analysis.

Z. Amoura and F. Cohen Aubart conducted the study coordination.

All the authors gave final approval of the submitted version. 
Abstract

Objective: Central nervous system localizations of sarcoidosis may be refractory to conventional treatment such as steroids and immunosuppressive drugs. Infliximab, a TNF- $\alpha$ antagonist chimeric antibody, has been shown to be effective for treatment of these localizations. The aim of this study was to evaluate the efficacy and safety, in particular the long-term outcomes, of the use of infliximab for the treatment of neurosarcoidosis.

Patients and methods: We retrospectively reviewed medical records of patients with neurosarcoidosis that had been treated with infliximab between 2009 and 2015. All patients had histologically proven non-caseating granulomas.

Results: Eighteen patients with histologically-proven sarcoidosis were included in this study. All had neurological involvement consisting of meningeal $(n=16)$, cerebral $(n=10)$, spinal cord $(n=6)$, and/or optic nerve $(n=5)$ involvement. Sixteen patients had previously received at least one immunosuppressive drug in addition to corticosteroids, including cyclophosphamide in 11 patients. All patients received treatment with infliximab (3-7.5 $\mathrm{mg} / \mathrm{kg}$ ) associated with corticosteroids ( $n=18)$, low-dose methotrexate $(n=15)$, azathioprine $(n=2)$, or mycophenolate $(n=1)$. Sixteen out of 18 patients improved clinically (initial median modified Rankin scale score of 3 , final median score of $1 ; p<0.0001)$. At 6 months after initiation of infliximab, 6 patients obtained complete remission (33\%), 10 attained partial remission (56\%), and 2 had stable disease (11\%). The median follow-up time was 20 months (range: 6-93). Nine patients relapsed during follow-up (50\%). Eight patients developed toxic side effects and 7 of these side effects were infectious events.

Conclusions: Infliximab is an efficacious treatment of refractory neurosarcoidosis. However, relapses frequently occurred during follow-up. (250 words) 
Sarcoidosis is a multi-systemic granulomatous disease of unknown cause characterized by the infiltration of the tissues by non-caseating granulomas. It can affect various organs and may remit spontaneously, although it can also be chronic or progressive in up to $25 \%$ of patients.[21] Clinical involvement of the nervous system occurs in approximately $5 \%$ of cases and may affect virtually any part of the peripheral (PNS) or central nervous system (CNS).[6, 8, 12, 13]

Corticosteroids are the drug of choice for managing neurosarcoidosis, but they may not be effective in some cases. A second-line immunosuppressive treatment (e.g., methotrexate (MTX), mycophenolate mofetil (MMF), or azathioprine (AZA)) may be used, although this may also be insufficient.[2] Most of the drugs used for sarcoidosis target tumor necrosis factor (TNF)- $\alpha$, which plays a crucial role in the initiation and development of the granulomatous process. Indeed, sarcoidosis is a Th1-Th17 disease leading to TNF-alpha synthesis by activated macrophages.[5] The efficacy of TNF- $\alpha$ antagonists has been reported in the literature for the treatment of pulmonary and extrapulmonary sarcoidosis, especially in patients who are refractory to corticosteroid therapy.[1,9] Infliximab is a chimeric immunoglobulin G monoclonal antibody directed against TNF- $\alpha$ that has been used in a randomized, double-blinded, placebo-controlled trial studying chronic corticosteroiddependent pulmonary sarcoidosis. The effect of infliximab on extrapulmonary sarcoidosis organ involvement has also been reported in this trial, as well as in several case reports and small open-labeled series.[9, 14] However, the long-term outcomes of patients with neurosarcoidosis treated with infliximab have not been reported. Thus, we conducted a retrospective multicenter study to evaluate the efficacy of infliximab for remission induction and long-term remission maintenance in patients with neurosarcoidosis and also to assess the tolerance of this drug. 


\section{Patients and Methods}

\section{Patient selection and inclusion criteria}

This is a retrospective multicenter study conducted at 2 University Hospitals and 1 general hospital from 2010 to 2015. Patients with a definite or probable diagnosis of neurosarcoidosis who received at least one infusion of infliximab were included.[23] The following criteria were used to diagnose neurosarcoidosis: (1) presence of clinical neurological signs, (2) compatible clinical, cerebro-spinal fluid analysis and radiological features, (3) presence of nervous system (definite) or extra-nervous system (probable) noncaseating granulomas, and (4) exclusion of differential diagnoses.

The study was conducted in compliance with the Good Clinical Practice protocol and the Declaration of Helsinki principles and was approved by the Institutional Review Board CPP Ile de France VI.

\section{Patient's characteristics}

Clinical, biological, and imaging data were retrospectively collected by practitioners in charge of the patients and were centrally reviewed by FCA. Baseline is defined as the time of initiation of infliximab. The modified Rankin scores were determined retrospectively at baseline and at the end of follow-up. Follow-up ended in December 2015.

\section{Efficacy and tolerance}

A complete neurological remission was defined by a neurological-related extra-pulmonary physician organ severity tool (ePOST) score of 0 . The ePOST score is the sum of 17 extrapulmonary organ activity scores ranging from 0 to 6 (from no activity to maximal activity) [9]. Thus the neurological-related ePOST score ranges from 0 to 6 . A partial neurological remission was defined by an improvement of at least 1 point of the neurological-related 
ePOST score. The stability of neurological involvement was defined by the absence of modification of the ePOST score. Progression of the neurological involvement was defined by an increase of at least 1 point of the neurological-related ePOST score. The same definitions were applied for the global ePOST score (17 extra-thoracic organs). A relapse was defined by an increase of at least 1 point of the ePOST score after a partial or complete remission (which corresponds to recurrence or occurrence of a new localization attributable to sarcoidosis). A relapse was classified as a neurological or extra-neurological depending of the modification of the neurological or extra-neurological ePOST scores. The primary endpoint was the number of complete or partial remissions at the 6 months follow-up. The secondary endpoint was the number of complete or partial remission at the end of the follow-up. The number of relapses was noted for each patient. All side effects were noted.

\section{Statistical analysis}

Data are presented as the median and range for continuous variables and as the number and percentage for categorical variables. Modified Rankin scores and daily steroids doses were compared between baseline and the end of follow-up using Wilcoxon and Mann-Whitney test, respectively. Statistical analyses were performed using the GraphPad Prism v 6.0 (GraphPad Software, La Jolla, CA, USA).

\section{Results}

\section{Patient's characteristics before infliximab initiation}

The characteristics of the patients are reported in the Table 1.

\begin{tabular}{|c|c|c|c|c|c|c|c|}
\hline Pati & Sex, & Sarcoidosis & Type of TNF- & Duration & Relapse(s) & Side & Concomitant \\
\hline
\end{tabular}




\begin{tabular}{|c|c|c|c|c|c|c|c|}
\hline ent & age* & $\begin{array}{c}\text { involvement } \\
\text { s (type of } \\
\text { CNS } \\
\text { involvement) }\end{array}$ & $\begin{array}{c}\alpha \text { antagonist } \\
\text { treatment } \\
\text { (dosage, } \\
\mathrm{mg} / \mathrm{kg} \text { ) }\end{array}$ & $\begin{array}{c}\text { of TNF- } \alpha \\
\text { antagonis } \\
t \\
\text { treatmen } \\
\quad t \\
\text { (months) }\end{array}$ & $\begin{array}{c}\text { (n, } \\
\text { localization } \\
\text { s of the } \\
\text { relapse(s)) }\end{array}$ & effect(s) & $\begin{array}{l}\text { treatments } \\
\text { (all had } \\
\text { corticosteroi } \\
\text { ds) }\end{array}$ \\
\hline$\# 1$ & $\begin{array}{l}M, \\
32\end{array}$ & $\begin{array}{c}\mathrm{T}, \mathrm{S}, \mathrm{O}, \mathrm{E} \\
(\mathrm{M}, \mathrm{C}, \mathrm{ON})\end{array}$ & $\begin{array}{c}\text { Infliximab (5 } \\
\text { then 3)ף }\end{array}$ & 93 & 0 & 0 & $\begin{array}{c}\text { MTX } 10 \\
\text { mg/week }\end{array}$ \\
\hline \#2 & $\begin{array}{l}M \\
29\end{array}$ & $\begin{array}{c}\mathrm{T}, \mathrm{O}, \mathrm{H} \\
(\mathrm{M}, \mathrm{CN})\end{array}$ & $\begin{array}{l}\text { Infliximab } \\
\text { (5)ף }\end{array}$ & 20 & $\begin{array}{c}1 \text { (after } \\
\text { withdrawal) } \\
\text {, CNS }\end{array}$ & $\begin{array}{l}\text { Pulmonary } \\
\text { infection }\end{array}$ & $\begin{array}{l}\text { MTX } 10 \\
\text { mg/week }\end{array}$ \\
\hline$\# 3$ & $F, 34$ & $\begin{array}{c}\mathrm{T} \\
(\mathrm{M}, \mathrm{C}, \mathrm{E}, \mathrm{ICH})\end{array}$ & $\begin{array}{l}\text { Infliximab } \\
\text { (5)ף }\end{array}$ & 45 & $2, \mathrm{CNS}$ & $\begin{array}{l}\text { Pulmonary } \\
\text { infection }\end{array}$ & $\begin{array}{c}\text { MTX } 10 \\
\text { mg/week }\end{array}$ \\
\hline$\# 4$ & $F, 45$ & $\begin{array}{c}T, E \\
(M, C, E, C N)\end{array}$ & $\begin{array}{c}\text { Infliximab } \\
\text { (5)ף }\end{array}$ & 56 & $2, \mathrm{CNS}$ & $\begin{array}{l}\text { Pulmonary } \\
\text { infection }\end{array}$ & $\begin{array}{c}\text { MTX } 10 \\
\text { mg/week }\end{array}$ \\
\hline \#5 & $F, 30$ & $\mathrm{~T}, \mathrm{~S}, \mathrm{E}(\mathrm{C}, \mathrm{CN})$ & $\begin{array}{c}\text { Infliximab } \\
\text { (5)ף }\end{array}$ & 56 & $\begin{array}{l}\text { 1, lung and } \\
\text { skin }\end{array}$ & $\begin{array}{l}\text { Pulmonary } \\
\text { infection }\end{array}$ & $\begin{array}{c}\text { MTX } 10 \\
\text { mg/week }\end{array}$ \\
\hline$\# 6$ & $\begin{array}{l}M \\
58\end{array}$ & $\begin{array}{c}\text { T, S } \\
(\mathrm{M}, \mathrm{C}, \mathrm{Med})\end{array}$ & $\begin{array}{c}\text { Infliximab (5 } \\
\text { then } 7.5 \text { ) }\end{array}$ & $12 \S$ & $\begin{array}{c}\text { 1, CNS } \\
\text { (after } \\
\text { withdrawal) }\end{array}$ & 0 & $\begin{array}{l}\text { MTX } 10 \\
\text { mg/week }\end{array}$ \\
\hline \#7 & $\begin{array}{l}M \\
49\end{array}$ & $\mathrm{~T}, \mathrm{O}(\mathrm{ON})$ & $\begin{array}{c}\text { Infliximab } \\
\text { (5) then } \\
\text { adalimumab } \\
\text { ๆ }\end{array}$ & 48 & 1, ocular & 0 & $\begin{array}{l}\text { MMF } 2 \\
\text { g/day }\end{array}$ \\
\hline \#8 & $F, 46$ & $\begin{array}{l}\mathrm{T}, \mathrm{S}, \mathrm{O}, \mathrm{H}(\mathrm{M}, \\
\text { Med, R, ON) }\end{array}$ & $\begin{array}{c}\text { Infliximab } \\
\text { (5)ף }\end{array}$ & 17 & 0 & $\begin{array}{l}\text { Cutaneous } \\
\text { abcess }\end{array}$ & $\begin{array}{c}\text { MTX } 10 \\
\text { mg/week }\end{array}$ \\
\hline \#9 & $\begin{array}{l}\mathrm{M}, \\
39\end{array}$ & $\mathrm{~T}, \mathrm{H}(\mathrm{M}, \mathrm{C}, \mathrm{E})$ & $\begin{array}{l}\text { Infliximab } \\
\text { (5)ף }\end{array}$ & 20 & $1, \mathrm{CNS}$ & 0 & $\begin{array}{c}\text { MTX } 10 \\
\text { mg/week }\end{array}$ \\
\hline$\# 10$ & $F, 48$ & $\begin{array}{l}\mathrm{T}(\mathrm{M}, \mathrm{Med}, \\
\mathrm{CN})\end{array}$ & $\begin{array}{l}\text { Infliximab } \\
\text { (5)ף }\end{array}$ & 11 & 0 & 0 & $\begin{array}{c}\text { MTX } 10 \\
\text { mg/week }\end{array}$ \\
\hline \#11 & $\begin{array}{l}M, \\
37\end{array}$ & $\begin{array}{c}T(M, C, E, \\
\text { Med) }\end{array}$ & $\begin{array}{l}\text { Infliximab } \\
\text { (5)ף }\end{array}$ & 18 & 0 & 0 & $\begin{array}{l}\text { MTX } 10 \\
\text { mg/week }\end{array}$ \\
\hline$\# 12$ & $F, 51$ & $\begin{array}{c}T, S, E \\
(M, C, E)\end{array}$ & $\begin{array}{l}\text { Infliximab (5 } \\
\text { then 3)ף }\end{array}$ & 72 & $\begin{array}{c}3 \text { (after } \\
\text { withdrawal) } \\
\text { multisyste } \\
\text { mic }\end{array}$ & 0 & $\begin{array}{c}\text { MTX } 10 \\
\text { mg/week } \\
\text { then } \\
\text { leflunomide }\end{array}$ \\
\hline \#13 & $\begin{array}{l}M \\
27\end{array}$ & $\begin{array}{c}\mathrm{T}, \mathrm{E} \\
(\mathrm{M}, \mathrm{C}, \mathrm{CN}, \\
\mathrm{ON})\end{array}$ & $\begin{array}{l}\text { Infliximab } \\
\text { (5)ף }\end{array}$ & 31 & 0 & 0 & $\begin{array}{c}\text { AZA } 1 \\
\mathrm{mg} / \mathrm{kg} / \mathrm{day}\end{array}$ \\
\hline \#14 & $\mathrm{M}$ & $\mathrm{T}, \mathrm{O}, \mathrm{E}(\mathrm{M})$ & Infliximab & 30 & 7 (after & Pulmonary & MTX 20 then \\
\hline
\end{tabular}




\begin{tabular}{|c|c|c|c|c|c|c|c|}
\hline & 39 & & (5)9 & & $\begin{array}{c}\text { withdrawal) } \\
\text {, CNS + O }\end{array}$ & infection & $\begin{array}{c}10 \mathrm{mg} / \text { week } \\
\text { then AZA } 2 \\
\mathrm{mg} / \mathrm{kg} / \text { day }\end{array}$ \\
\hline$\# 15$ & $F, 37$ & $\mathrm{~T}(\mathrm{M}, \mathrm{Med}, \mathrm{R})$ & $\begin{array}{l}\text { Infliximab } \\
\text { (3)ף }\end{array}$ & 15 & 0 & $\begin{array}{c}\text { CMV } \\
\text { infection }\end{array}$ & $\begin{array}{c}\text { MTX } 10 \\
\text { mg/week }\end{array}$ \\
\hline \#16 & $\begin{array}{l}M, \\
33\end{array}$ & $\mathrm{~T}(\mathrm{M}, \mathrm{C}, \mathrm{E})$ & $\begin{array}{l}\text { Infliximab } \\
\text { (7.5)ף }\end{array}$ & 13 & 0 & 0 & $\begin{array}{c}\text { AZA } 1 \\
\mathrm{mg} / \mathrm{kg} / \text { day }\end{array}$ \\
\hline$\# 17$ & $\begin{array}{l}M, \\
39\end{array}$ & $\mathrm{O}, \mathrm{E}(\mathrm{M}, \mathrm{ON})$ & $\begin{array}{c}\text { Infliximab } \\
\text { (5) then } \\
\text { adalimumab } \\
\text { ๆ }\end{array}$ & 12 & 0 & alopecia & $\begin{array}{l}\text { MTX } 10 \\
\text { mg/week }\end{array}$ \\
\hline \#18 & $\begin{array}{l}M, \\
30\end{array}$ & $\begin{array}{c}\text { T, E (M, E, } \\
\text { Med) }\end{array}$ & $\begin{array}{l}\text { Infliximab } \\
\text { (5)ף }\end{array}$ & 6 & 0 & 0 & $\begin{array}{l}\text { MTX, } 10 \\
\text { mg/week }\end{array}$ \\
\hline
\end{tabular}

Table 1. Demographic and clinical characteristics of the 18 patients. *age at sarcoidosis diagnosis 9 patient still treated at the end of follow-up, AZA: azathioprine, MMF mycophenolate mofetil, MTX methotrexate $\S$ dead during follow-up (after infliximab discontinuation); $\mathrm{T}$ thoracic, S skin, $\mathrm{O}$ ophthalmologic, E ear-nose-throat, $\mathrm{H}$ heart For CNS involvement: $\mathrm{M}$ denotes meningeal involvement, $\mathrm{C}$ cerebral, Med medullar, $\mathrm{R}$ radiculopathy, $\mathrm{CN}$ cranial nerves (other than optic nerves), ON optic nerves, E epilepsy, ICH intracranial hypertension.

Eighteen patients (11 males, 7 females) were included in the study. The median age at the time of sarcoidosis diagnosis was 38 years (range: $27-51$ ). Neurological manifestations consisted of meningeal involvement $(n=16)$, cerebral localization $(n=10)$, cranial nerves involvement $(n=9)$, myelitis $(n=6)$, and radicular infiltration $(n=2)$. Seven patients had epilepsy, and 1 had intracranial hypertension. Additionally, 5 patients had pituitary involvement. Five patients had optic nerve involvement.

Sarcoidosis involved mainly the lungs and/or mediastinal lymph nodes $(n=17)$, peripheral lymph nodes $(n=12)$, ear-nose-throat $(E N T)(n=8)$, eyes $(n=6)$, skin $(n=5)$ and heart $(n=3)$. Ten patients had stage I and 7 patients had stage 2 disease based on chest X-ray findings.

Sixteen patients had an extra-neurological histological proof of non-caseating granulomas, obtained from lymph nodes $(n=6)$, bronchial tissue $(n=4)$, skin $(n=4)$, minor salivary gland 
$(n=3)$, and/or ENT tissues ( $n=2)$ (some patients had several biopsies). Additionally, 2 patients had histologically proven non-caseating granuloma obtained from CNS tissue (meningeal tissue from spinal and optic nerve localizations, respectively).

Before receiving infliximab, all patients had been treated with steroids in association with at least one immunosuppressive drug in 16 patients: cyclophosphamide (CYC) ( $n=11)$, MTX $(n=10), \operatorname{MMF}(n=3)$, hydroxychloroquine (HCQ) $(n=1)$ or cyclosporine $(n=1)$. The median number of lines of immunosuppressive therapies, in addition to steroids, before infliximab was 1.5 (range: 0-3). The median duration of treatment before infliximab therapy was 24 months (ranging from 1 to 60).

\section{Infliximab treatment}

Infliximab was initially administered intravenously at a dose of $5 \mathrm{mg} / \mathrm{kg}$ in 16 patients, 3 $\mathrm{mg} / \mathrm{kg}$ in 1 patient, and $7.5 \mathrm{mg} / \mathrm{kg}$ in 1 patient. Initially, all patients received two infusions given at 2-week intervals, then 15 patients received an infusion every 4 weeks during the first 6 months, and 2 patients received infusions every 6 weeks. One patient developed a severe cutaneous side effect after the administration of 2 infliximab perfusions and was subsequently switched to adalimumab. After the first 6 months, the interval between infusions was heterogeneous and varied between 4 to 8 weeks (median, 6 weeks). An additional patient was switched to adalimumab after 6 infliximab infusions. Infliximab was administered in combination with low-dose MTX (7.5 to 20 milligrams/week; median dose, $10 \mathrm{mg}$ ) in 15 patients. One patient received combined therapy with MMF 2 gm/day, and 2 patients received a $1 \mathrm{mg} / \mathrm{kg} /$ day AZA treatment in addition to infliximab. All patients received corticosteroids during infliximab treatment.

At 6 months after baseline, 6 (33\%) patients had complete neurological remission, 10 (56\%) had partial neurological remission and $2(11 \%)$ were stable. Overall, partial or complete 
remission was obtained in 16 (89\%) patients with a statistically significant decrease in the daily steroid dose (median daily dose at baseline was $50 \mathrm{mg} /$ day and at the last visit, it was 5 $\mathrm{mg} /$ day, $\mathrm{p}<0.0001$ ) (Figure). A significant decrease in the modified Rankin score was also observed (from 3 at baseline to 1 at the last visit, $p<0.0001$ ) (Figure).

\section{Follow-up}

The median follow-up time was 20 months (range 6-93). TNF-alpha antagonist treatment was discontinued in 4 patients due to an absence of efficacy ( $n=1$, patient \#6, this patient had been considered as "stable", without clinical improvement), complete remission without disease activity ( $n=2$, patients \#12 and \#14), or loss to follow-up ( $n=1$, patient \#2).

During infliximab treatment, five of 14 (36\%) patients relapsed during the follow-up period and 4/4 (100\%) after infliximab withdrawal (relapse in 3 and disease progression in 1). Among the 5 patients who relapsed during infliximab treatment, 3 had a CNS flare, 1 had an ophthalmologic flare and 1 had a lung and skin flare. Relapses occurred when the interval between the infusions was 5 or 6 weeks. Patients with a relapse were treated by increasing the daily steroid dose and decreasing the interval between infliximab perfusions. Among the 4 patients who relapsed after infliximab discontinuation (patients \#2, \#6, \#12, \#14), improvement occurred after the infliximab treatment was resumed in 3 of them (the patient \#6 who experienced a disease progression was not re-treated with infliximab). Among these 4 patients, the flare consisted of multisystemic disease for 2 patients and a CNS flare or progression for 2 .

At the end of the follow-up, 16 patients (89\%) were still being treated with TNF- $\alpha$ antagonists (14 with infliximab and 2 with adalimumab). One patient died (\#6), and another was lost to follow-up (\#13). At the end of follow-up, 5 patients had a complete remission (31\%), 10 had a partial remission (63\%), and 1 was stable (6\%). Patient \#6 died during follow- 
up of unknown cause (sudden death without an autopsy) after infliximab interruption (for absence of efficacy) and despite steroid and MMF treatment. As shown in the Figure, the median daily steroid dose at the end of follow-up was 5 milligrams (0-12.5 range) that was significantly lower than the dose at the beginning of treatment.

\section{Safety}

Eight patients experienced toxic side effects. Infectious events occurred in 7 patients (39\%) consisting of: pulmonary infections requiring hospitalisations $(n=5,4$ without bacteriologic documentation, 1 with Pseudomonas aeruginosa and atypical mycobacteria), cellulitis ( $n=1)$, and cytomegalovirus primo-infection with fever, and cytolysis $(n=1)$. All but one infectious adverse events occurred during the first year of infliximab treatment. Additionally, one patient developed severe alopecia that required infliximab interruption (this patient was subsequently treated with adalimumab).

\section{Discussion}

This multicenter, collaborative study reports the efficacy of infliximab for the management of neurosarcoidosis with a focus on long-term outcomes. Infliximab displayed a high rate of efficacy ( $89 \%)$, although sometimes it is given as a $4^{\text {th }}$ line immunosuppressive therapy. However, the results from this study show a high rate of relapse (50 \%) during follow-up, including patients who were receiving TNF- $\alpha$ antagonist treatment (35\%), and despite maintenance therapy in others. The safety profile of infliximab for management of neurosarcoidosis was marked by the occurrence of infectious events (39\%), possibly facilitated by a history of several lines of immunosuppressive treatments more than cumulative infliximab treatment. 
Infliximab is increasingly prescribed for neurosarcoidosis.[7] In a prospective randomized placebo-controlled study, 13 patients who received infliximab had nervous system involvement, while 7 patients who received placebo had nervous system involvement[9]. The patients received corticosteroids in the 2 arms of the study. Two patients in the infliximab group had a complete remission at W24 compared with 0 in the placebo group. There were no details provided regarding the neurological ePOST scores. The efficacy of infliximab has also been studied in small series and case reports of patients with neurosarcoidosis(Table 2).[3, 4, 10, 11, 14-20]

$\mathrm{n}=\mathbf{3 8}$ cases

\begin{tabular}{|c|c|}
\hline Age (mean, range) & 41.7 years $(22-74)$ \\
\hline Sex ratio (M/W) & $20 \mathrm{~W} / 18 \mathrm{M}$ \\
\hline \multicolumn{2}{|l|}{ Neurological involvement $(n, \%)$} \\
\hline Cerebral or meningeal & $27(71 \%)$ \\
\hline Myelitis & $14(37 \%)$ \\
\hline Cranial nerves & $10(26 \%)$ \\
\hline Optic nerves & $5(13 \%)$ \\
\hline \multicolumn{2}{|l|}{ Extra-neurological localizations } \\
\hline Thoracic (lung or lymph nodes) & $27 / 32(84 \%)$ \\
\hline Eyes & $2 / 32(6 \%)$ \\
\hline Sinus & $2 / 32(6 \%)$ \\
\hline \multicolumn{2}{|l|}{ Previous treatments (n, \%) } \\
\hline Corticosteroids & $38(100 \%)$ \\
\hline Methotrexate & $13(34 \%)$ \\
\hline Mycophenolate mofetil & $6(16 \%)$ \\
\hline Cyclophosphamide & $10(26 \%)$ \\
\hline Azathioprine & $10(26 \%)$ \\
\hline Ciclosporin & $2(5 \%)$ \\
\hline Leflunomide & $1(3 \%)$ \\
\hline Plasmatic exchange & $1(3 \%)$ \\
\hline \multicolumn{2}{|l|}{ Type of TNF-alpha antagonists (n, \%) } \\
\hline Etanercept & 1 (before infliximab) \\
\hline Adalimumab & 1 (+1 after infliximab) \\
\hline infliximab & $36(95 \%)$ \\
\hline \multicolumn{2}{|l|}{ Reason for TNF-alpha antagonist treatment } \\
\hline Previous treatments failure & $35(92 \%)$ \\
\hline Previous treatments intolerance & 1 (CYC induced alopecia) \\
\hline Steroid-sparing effect & $2(5 \%)$ \\
\hline Efficacy* & $38(100 \%)$ \\
\hline
\end{tabular}


Table 2. Results of previously published cases of biopsy-proven neurosarcoidosis treated with TNF-alpha antagonists (cases without histology were not included, as well as those from studies not focusing on neurosarcoidosis). *Efficacy rate could have been influenced by a publication bias. CYC cyclophosphamid

Thirty-eight cases with biopsy-proven neurosarcoidosis treated with TNF-alpha antagonists have been reported so far (excluding patients with non-histologically proven sarcoidosis and those from studies which did not focus on neurosarcoidosis). Infliximab has been shown to demonstrate short-term efficacy in these patients, even in case of previous immunosuppressive drugs failure, as we observed in our study. Of note, other immunosuppressive drugs given concomitantly to TNF-alpha antagonists may have help to the efficacy as in our series. Relapse rates after infliximab withdrawal were high, as previously reported.[22] However, our study also demonstrated a high relapse rate even during TNF-alpha antagonist treatment. This may be due to the blood-brain barrier leading to high rate of relapses even during infliximab treatments. These relapses occurred after increasing the time interval between infusions, suggesting that a regimen of $5 \mathrm{mg} / \mathrm{kg}$ infusion administered every 4 weeks could be maintained for a long time for CNS sarcoidosis patients. We did not have any information about neutralizing antibodies against infliximab in our patients, in particular among those who relapsed.

Our study has several limitations. The retrospective design and absence of placebo-arm does not allow us to give high-level evidence conclusions about the efficacy of infliximab. However, due to the severity of disease in these patients, a placebo-controlled trial does not seem ethically possible. In particular, 11 patients had previously received a CYC treatment in our series. Another limitation for the interpretation of data, in particular the rate of relapse, is that the infliximab dosage and interval between perfusions were heterogeneous. Finally, 
some side effects may have not been recognized or noted due to the retrospective study design.

In conclusion, infliximab seems to be an efficacious treatment for refractory

neurosarcoidosis but has a high rate of relapses. Prospective studies to examine combined therapies and treatment duration should be considered, despite the small number of patients. 


\section{References}

1. Baughman RP, Drent $M$, Kavuru $M$, Judson MA, Costabel U, du Bois R, Albera C, Brutsche $M$, Davis G, Donohue JF, Muller-Quernheim J, Schlenker-Herceg R, Flavin S, Lo KH, Oemar B, Barnathan ES, Sarcoidosis I (2006) Infliximab therapy in patients with chronic sarcoidosis and pulmonary involvement. American journal of respiratory and critical care medicine 174:795802

2. Baughman RP, Winget DB, Lower EE (2000) Methotrexate is steroid sparing in acute sarcoidosis: results of a double blind, randomized trial. Sarcoidosis, vasculitis, and diffuse lung diseases : official journal of WASOG / World Association of Sarcoidosis and Other Granulomatous Disorders 17:60-66

3. Carter JD, Valeriano J, Vasey FB, Bognar B (2004) Refractory neurosarcoidosis: a dramatic response to infliximab. The American journal of medicine 117:277-279

4. Chintamaneni S, Patel AM, Pegram SB, Patel H, Roppelt H (2010) Dramatic response to infliximab in refractory neurosarcoidosis. Annals of Indian Academy of Neurology 13:207-210

5. Cinetto F, Agostini C (2016) Advances in understanding the immunopathology of sarcoidosis and implications on therapy. Expert review of clinical immunology:1-16

6. Delaney P (1977) Neurologic manifestations in sarcoidosis: review of the literature, with a report of 23 cases. Annals of internal medicine 87:336-345

7. Drent M, Cremers JP, Jansen TL, Baughman RP (2014) Practical eminence and experiencebased recommendations for use of TNF-alpha inhibitors in sarcoidosis. Sarcoidosis, vasculitis, and diffuse lung diseases : official journal of WASOG / World Association of Sarcoidosis and Other Granulomatous Disorders 31:91-107

8. Ferriby D, de Seze J, Stojkovic T, Hachulla E, Wallaert B, Destee A, Hatron PY, Vermersch P (2001) Long-term follow-up of neurosarcoidosis. Neurology 57:927-929

9. Judson MA, Baughman RP, Costabel U, Flavin S, Lo KH, Kavuru MS, Drent M, Centocor TSI (2008) Efficacy of infliximab in extrapulmonary sarcoidosis: results from a randomised trial. The European respiratory journal 31:1189-1196

10. Kobylecki C, Shaunak S (2007) Refractory neurosarcoidosis responsive to infliximab. Practical neurology 7:112-115

11. Lorentzen AO, Sveberg L, Midtvedt O, Kerty E, Heuser K (2014) Overnight response to infliximab in neurosarcoidosis: a case report and review of infliximab treatment practice. Clinical neuropharmacology 37:142-148

12. Lower EE, Broderick JP, Brott TG, Baughman RP (1997) Diagnosis and management of neurological sarcoidosis. Archives of internal medicine 157:1864-1868

13. Luke RA, Stern BJ, Krumholz A, Johns CJ (1987) Neurosarcoidosis: the long-term clinical course. Neurology 37:461-463

14. Moravan M, Segal BM (2009) Treatment of CNS sarcoidosis with infliximab and mycophenolate mofetil. Neurology 72:337-340

15. Morcos Z (2003) Refractory neurosarcoidosis responding to infliximab. Neurology 60:12201221; author reply 1220-1221

16. O'Reilly MW, Sexton DJ, Dennedy MC, Counihan TJ, Finucane FM, O'Brien T, O'Regan AW (2015) Radiological remission and recovery of thirst appreciation after infliximab therapy in adipsic diabetes insipidus secondary to neurosarcoidosis. QJM : monthly journal of the Association of Physicians 108:657-659

17. Pereira J, Anderson NE, McAuley D, Bergin P, Kilfoyle D, Fink J (2011) Medically refractory neurosarcoidosis treated with infliximab. Internal medicine journal 41:354-357 
18. Pettersen JA, Zochodne DW, Bell RB, Martin L, Hill MD (2002) Refractory neurosarcoidosis responding to infliximab. Neurology 59:1660-1661

19. Santos E, Shaunak S, Renowden S, Scolding NJ (2010) Treatment of refractory neurosarcoidosis with Infliximab. Journal of neurology, neurosurgery, and psychiatry 81:241246

20. Sollberger M, Fluri F, Baumann T, Sonnet S, Tamm M, Steck AJ, Brutsche M (2004) Successful treatment of steroid-refractory neurosarcoidosis with infliximab. Journal of neurology 251:760-761

21. Valeyre D, Prasse A, Nunes H, Uzunhan Y, Brillet PY, Muller-Quernheim J (2014) Sarcoidosis. Lancet 383:1155-1167

22. Vorselaars AD, Verwoerd A, van Moorsel CH, Keijsers RG, Rijkers GT, Grutters JC (2014) Prediction of relapse after discontinuation of infliximab therapy in severe sarcoidosis. The European respiratory journal 43:602-609

23. Zajicek JP, Scolding NJ, Foster O, Rovaris M, Evanson J, Moseley IF, Scadding JW, Thompson EJ, Chamoun V, Miller DH, McDonald WI, Mitchell D (1999) Central nervous system sarcoidosis--diagnosis and management. QJM : monthly journal of the Association of Physicians 92:103-117 